\title{
Strong Cellular Preference in the Expression of a Housekeeping Gene of Arabidopsis thaliana Encoding S-Adenosylmethionine Synthetase
}

\author{
Johan Peleman, ${ }^{a}$ Wout Boerjan, ${ }^{a}$ Gilbert Engler, ${ }^{a}$ Jef Seurinck, ${ }^{b}$ Johan Botterman, ${ }^{b}$ Thierry Alliotte, \\ Marc Van Montagu, ${ }^{\text {a,2 }}$ and Dirk Inzé ${ }^{a}$ \\ a Laboratorium voor Genetica, Rijksuniversiteit Gent, K.L. Ledeganckstraat 35, B-9000 Gent, Belgium \\ 'Plant Genetic Systems N.V., Plateaustraat 22, B-9000 Gent, Belgium
}

\begin{abstract}
S-Adenosylmethionine serves as a methyl group donor in numerous transmethylation reactions and plays a role in the biosynthesis of polyamines and ethylene. We have cloned and sequenced an S-adenosylmethionine synthetase gene (sam-1) of Arabidopsis thaliana. The deduced polypeptide sequence of the enzyme has extensive homology with the corresponding enzymes of Escherichia coli and yeast. Genomic hybridization indicates the presence of two adenosylmethionine synthetase genes per haploid Arabidopsis genome. RNA gel blot analysis shows that adenosylmethionine synthetase mRNA levels are high in stems and roots, correlating well with the higher enzyme activity in stems, compared with leaves. Histochemical analysis of transgenic Arabidopsis plants transformed with a chimeric $\beta$-glucuronidase gene, under the control of 748-base pair 5' sequences of the sam-1 gene, demonstrates that the gene is expressed primarily in vascular tissues. In addition, high expression was observed in sclerenchyma and in the root cortex. A hypothesis for the strong cellular preference in the expression of the sam-1 gene is presented.
\end{abstract}

\section{INTRODUCTION}

S-Adenosylmethionine synthetase (AdoMet synthetase or ATP:L-methionine S-adenosyltransferase, EC 2.5.1.6) is an enzyme that catalyzes the only known biosynthesis of $S$ adenosylmethionine (AdoMet) by the following reaction (for review, see Tabor and Tabor, 1984):

$$
\text { Methionine + ATP } \underset{\mathrm{K}^{+}}{\stackrel{\mathrm{Mg}^{2+}}{\longrightarrow}} \text { AdoMet }+\mathrm{PPi}+\mathrm{Pi}
$$

In all living organisms AdoMet serves as a cofactor in a variety of reactions. It acts as a methyl group donor in numerous highly specific transmethylations involving various kinds of acceptor macromolecules, such as proteins, lipids, polysaccharides, and nucleic acids. AdoMet also serves, after decarboxylation by AdoMet decarboxylase, as a propylamine group donor in the biosynthesis of polyamines. In plants, AdoMet is a precursor molecule in the biosynthesis of the phytohormone ethylene (Yang and Hoffman, 1984). In addition, AdoMet is believed to play a regulatory role in the synthesis of methionine and other aspartate-derived amino acids. Known examples of such

'Current address: L'Air Liquide, S.A., 75, Quai d'Orsay, F-75321 Cedex 07, Paris, France.

${ }^{2}$ To whom correspondence should be addressed. regulation in plants by AdoMet are the feedback inhibition of AdoMet synthetase and the allosteric stimulation of threonine synthetase (Giovanelli et al., 1980).

AdoMet synthetase has been studied extensively in bacteria, yeast, and animal systems. In Escherichia coli the enzyme consists of four identical subunits (Markham et al., 1980). MetK, the structural gene for the enzyme, has been cloned and sequenced (Markham et al., 1984). In Saccharomyces cerevisiae AdoMet synthesis is catalyzed by two isoenzymes encoded by two different genes (sam-1 and sam-2), which have been cloned recently (Cherest et al., 1978; Thomas and Surdin-Kerjan, 1987). Three isoenzymes, $\alpha, \beta$, and $\gamma$, have been identified in mammalian tissues (Abe et al., 1980; Suma et al., 1986). In plants, AdoMet synthetase activity has been shown in barley and pea (Mudd, 1960; Aarnes, 1977). In these studies the plant enzymes seem to have the same properties as the yeast and mammalian AdoMet synthetase: requirement of $\mathrm{Mg}^{2+}$ and a monovalent cation and inhibition by tripolyphosphate. No AdoMet synthetase genes from higher eukaryotes have been cloned yet.

In this paper we present the characterization of an AdoMet synthetase gene, sam-1, of Arabidopsis thaliana. We show that the gene is expressed at high levels in stems and roots and identify the cell types in which the gene is expressed most abundantly. 


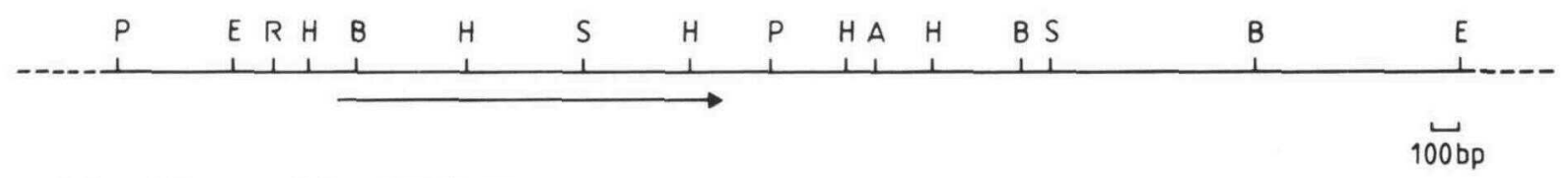

Figure 1. Restriction map of the sam-1 Gene.

Arrow indicates the transcribed region. A, Aval; B, Bglll; E, EcoRI; H, Hindlli; P, Pstl; R, EcoRV; S, Sall.

\section{RESULTS}

\section{Isolation of the sam-1 Gene and RNA Gel Blot Analysis}

A genomic sublibrary of $A$. thaliana containing 1145 randomly chosen cosmid clones was differentially screened with cDNA probes of poly $(A)^{+}$RNA preparations from different organs of Arabidopsis (Simoens et al., 1988). One of the clones, pATC9A1, was chosen for further investigation because it reproducibly gave strong hybridization signals with cDNA probes of stem and callus poly $(A)^{+}$RNA (Simoens et al., 1988).

To localize the gene on the pATC9A1 plasmid, several restriction digests were blotted and hybridized with a cDNA probe of stem poly $(\mathrm{A})^{+} \mathrm{RNA}$. Figure 1 shows a restriction map of the gene. Different restriction fragments containing the gene were subcloned in the riboprobe system vector pGem1 (see "Methods").

The expression pattern of the gene in the different organs of Arabidopsis was determined by RNA gel blot hybridizations. Riboprobes transcribed from the 0.78-kb Bglll-Sall fragment of the coding region (Figure 1) were hybridized with RNA gel blots containing total RNA isolated from leaves, stems, roots, inflorescences, seed pods, and callus tissue of Arabidopsis. A very abundant transcript of approximately $1.3 \mathrm{~kb}$ was detected in the RNA of stems, roots, and callus tissue (Figure $2 \mathrm{~A}$ ). The transcript is 10 to 20 times less abundant in leaf, seed pod, and inflorescence RNA.

\section{Sequence Analysis of the sam-1 Gene}

Figure 3 shows the sequence of a 2560-bp Pstl-Aval fragment containing the gene. The sequence contains one large open-reading frame of $1182 \mathrm{bp}$, coding for a putative protein of 394 amino acids, starting from the ATG at position +9 to a stop codon at position +1191 . This putative protein has a calculated molecular size of 43,149 D.

The significance of the open-reading frame was further underlined by analysis of a homologous cDNA clone. A cDNA library of poly $(\mathrm{A})^{+}$RNA from mature Arabidopsis plants was constructed as described in "Methods." Upon screening of 10,000 cDNA clones, 18 clones hybridized with a riboprobe transcribed from the $0.78-\mathrm{kb}$ Bglll-Sall fragment containing part of the open reading frame. A cDNA clone, pATCC9A1-2, containing an insert of 1258 bp was chosen for sequence analysis. Figure 3 shows that the cDNA sequence is colinear and $98 \%$ identical to the genomic sequence. Since the cDNA and the genomic bank are derived from different varieties of $A$. thaliana (see "Methods"), the $2 \%$ mismatches can be attributed to gene polymorphism between the two varieties. Screening of the NBRF data bank (release 14) with the protein sequence encoded by the open reading frame as a probe revealed extensive homology with the AdoMet synthetase protein sequences of $E$. coli and yeast (Figure 4). The deduced amino acid sequence of the Arabidopsis AdoMet synthetase is $49 \%$ homologous to the E. coli and $57 \%$ to the yeast AdoMet synthetase polypeptide (Markham et al., 1984; Thomas and Surdin-Kerjan, 1987). The highest degree of conservation between the three compared sequences is found in two domains, one at the amino terminus (between residues 1 and 49) and another one in the middle of the polypeptide (between residues 237 and 289).

The transcription start of the sam-1 gene was determined by $\mathrm{S} 1$ mapping. A 5 '-labeled 295-bp EcoRV-BgllI fragment was hybridized to RNA from leaves, stems, and

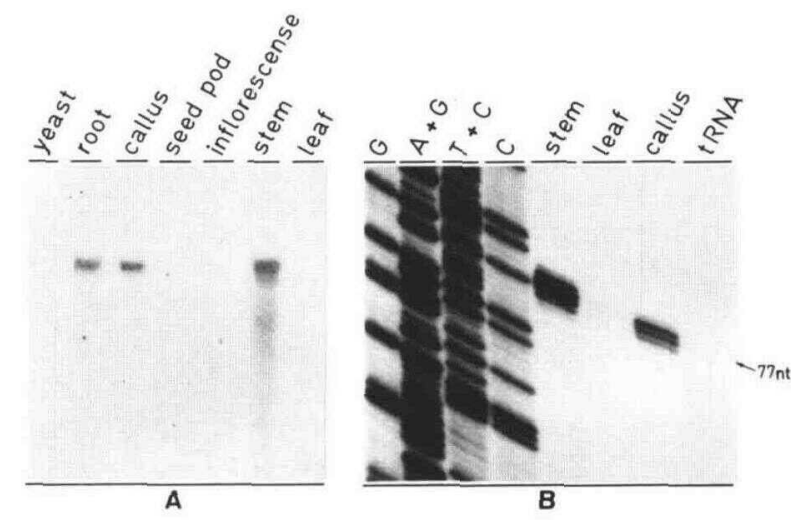

Figure 2. Expression Analysis and Transcription Start Mapping of the sam-1 Gene.

(A) RNA gel blot with $20 \mu \mathrm{g}$ of total RNA from different organs of Arabidopsis hybridized with the $0.78-\mathrm{kb}$ Bglll-Sall fragment of the sam-1 gene as a probe. The hybridization was performed as described in "Methods."

(B) Transcription start mapping of the sam-1 gene. Fifty $\mu \mathrm{g}$ of total RNA from stem, leaf, and callus tissue, and $50 \mu \mathrm{g}$ of tRNA were hybridized with the 295-bp EcoRV-Bglll fragment of the sam-1 gene labeled at the $5^{\prime}$ end of the Bglll site. The hybrids were digested subsequently with $\mathrm{S} 1$ nuclease and after ethanol precipitation the samples were run on a $6 \%$ DNA-sequencing gel next to a Maxam and Gilbert sequencing ladder as a size marker (for details, see "Methods"). 
625 AATTGGTATTITAGCTTTAGTTTTAATGAGTCTTTAAGTTGTTTTTCAAGTTTGAATAAGCTCCTGgTTTGTAGgaGTCAAGTAGTAGTGGTCCTAGTCATTAGTTTACTTCCGCAAGTC

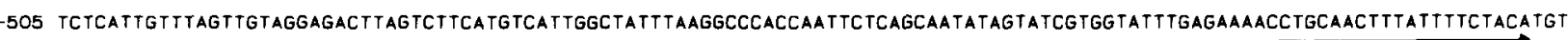

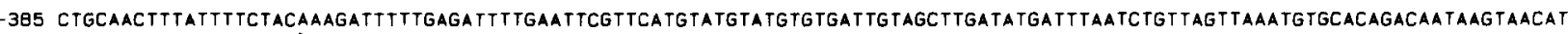

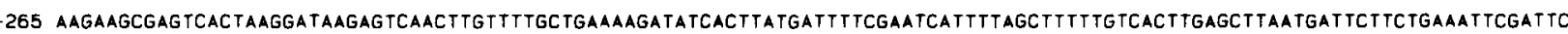

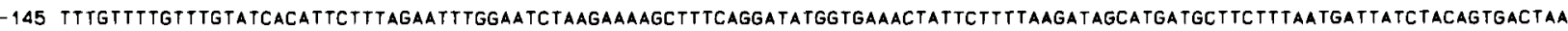

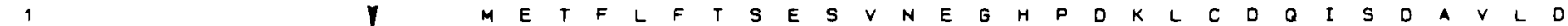

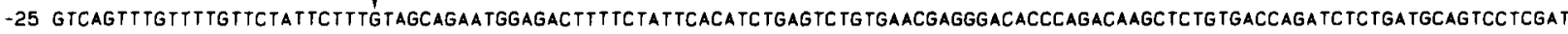

3O A C L L E O

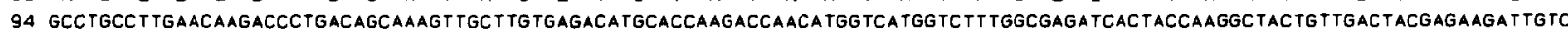

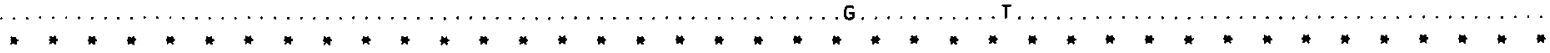

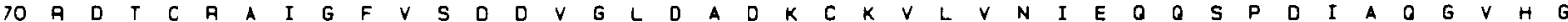
214 CGTGACACCTGTCGCGCCATTGgATTCGTCTCTGATGATGTTGGTCTIGATGCTGACAAATGCAAAGTCCTAGTCAACATTGAGCAACAGAGCCCAGATATTGCTCAAGgAGTTCACGgT

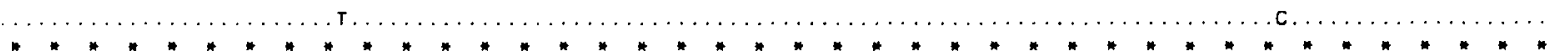

110 H F F $T$ K C C P

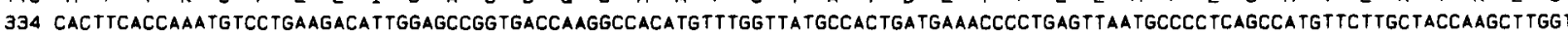

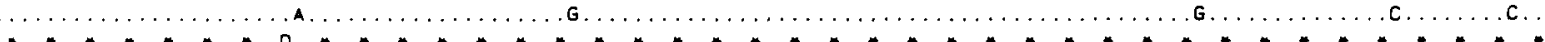

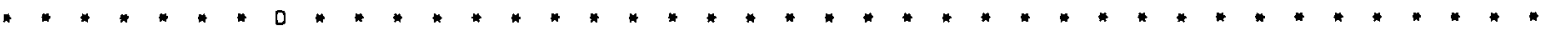

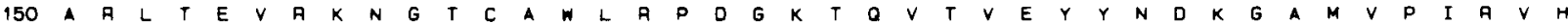

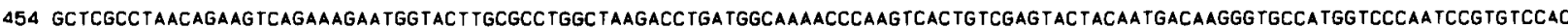

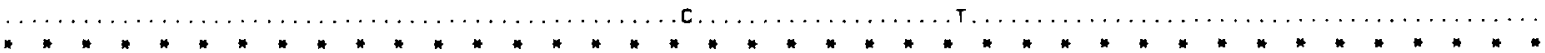

190 T $V$ L

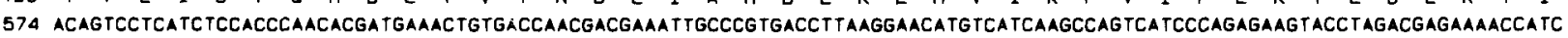

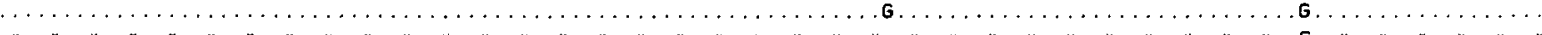

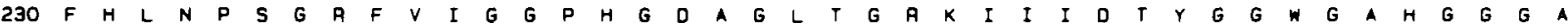

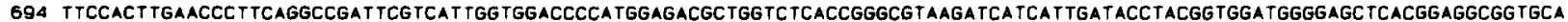

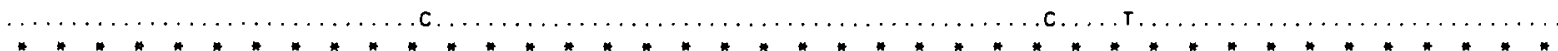

270 F S G K D P $T$ K V D A S G A Y I V A A O A A K S V V A N G M A A A A L V O V S Y A

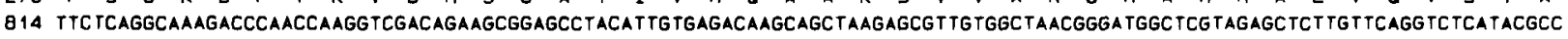

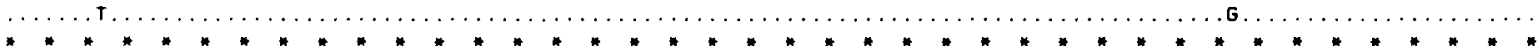

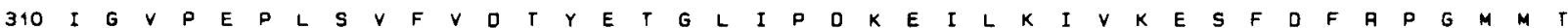
934 aTTGGAGTCCCTGAGCCATTGTCTGTCTTTGTGgACACTTACGAGACTGGATTGATTCCAGACAAGgAGATACTAAAGATTGTGAAGGGAGCTTCGACTTCAGACCAGGAATGATGACA

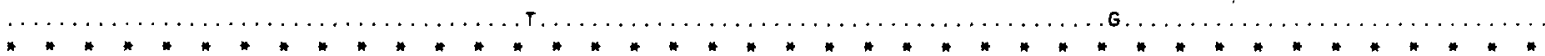

350 I N L D L $K$ A $G$ G $N$ G A F $L$ G $K$ T A A

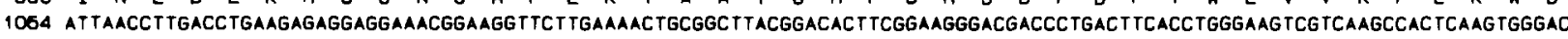

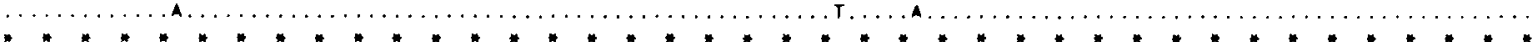

$390 \times P O$

1174 AAACCTCAAGCTTAAATTTTACCTACTCTGTTTCTGTCTTCATTCCACAAACCAATTATCTGCTCACTTTITTATTTCTCTGTTTTTGTGGTTTATTG TGTTTATGTATAATTGTACTTG

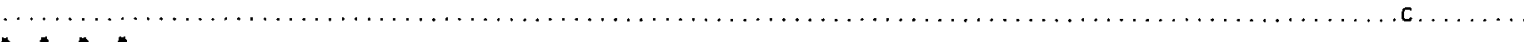

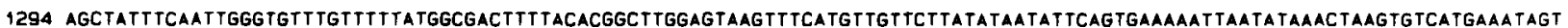
AGCTATTTCAATTKGGT

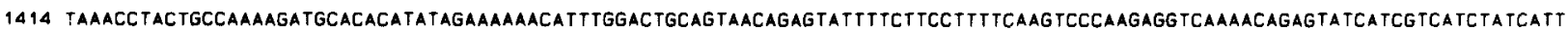

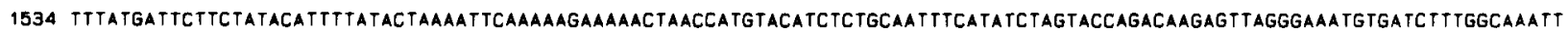

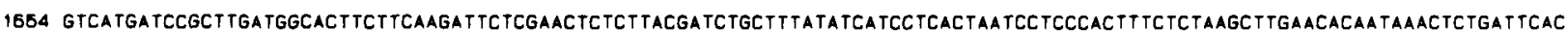
1774 TAATCGCAaACCAACAaCAagaAaACTCAATCAGTAagCAaAaA

Figure 3. Nucleotide Sequence of the sam-1 Gene.

The deduced amino acid sequence is indicated above the nucleotide sequence. The homology with the cDNA clone pATCC9A1-2 is represented below the sam-1 gene sequence by dots. Only the mismatches with the sam-1 sequence are indicated. The amino acid sequence deduced from the cDNA clone is shown below the cDNA sequence. Amino acids identical with those deduced from the sam-1 gene are indicated with asterisks. The transcription start site of the sam-1 gene is indicated with a vertical arrow. The direct repeat of 20 bp is underlined with horizontal arrows. 
2 Sam-1 Yeast

3 Sam-1 Aradidopsis

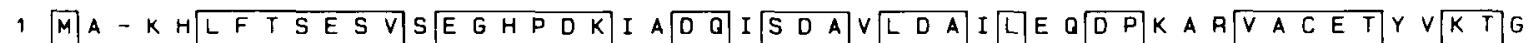
2 MA G T F L F T SE S V G E G H P D K I C D O V S S D A I L D D A C L L A E D D P H S K V V A C C E T A A A K T G

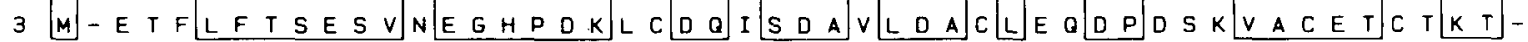

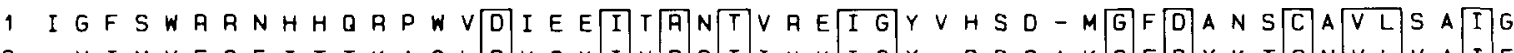
2 - MI MVFGE I T T K A Q L L D Y O K K I V R R D T I K K I I G Y Y - D D S A K K G F D Y Y K T 3 N M V M VF G E I T T K A T V D Y Y E K I V V B D T C C R A I G

1 KOSPDINAGV- - DRADPLE OGAGDQGLDVSATQLMKFTCLMPAPITYAH

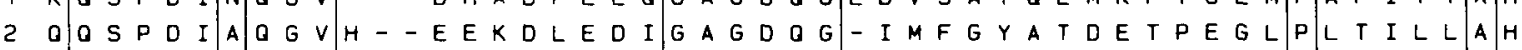
3 OQSPDI ALGVHGHFTKCPEDIGAGDOGG-HMFGYATDETPELMDLSHVLLJT

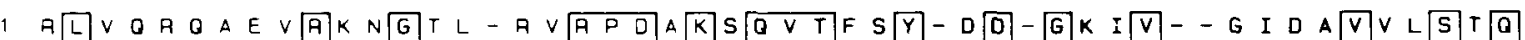

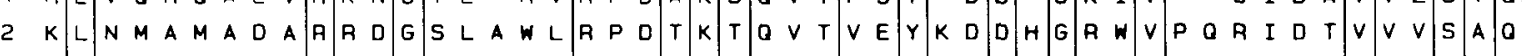

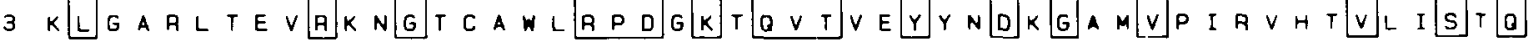

1 HSEEIDQKSLOEAVMEE I IKP I LPAEWLTSATKFF I NPTGAFVIGGPMGD 2 H A D D E I I T T E D L R A

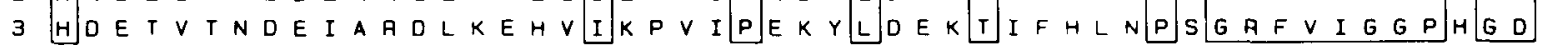

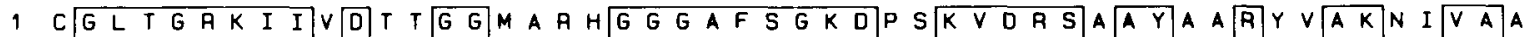
2 T G L T G R K I I I V D A Y G G G A S S V G G G G A F S G K D 3 A GLTGG A K I I I D T Y G G W G A H G G G A F S G K D P T K V D A S G G Y Y I V $V$ G

1 GLADACEI OVISYAIGLAEPTSIMVETFG TEKVPSEOLTLLVAEFFDL - PI

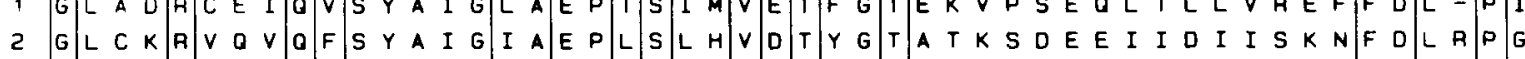
3 G M A A B A L V O O V S S Y A I G G V P E P L L S V F V D T Y Y E T G L I P D K K E I L K K I V V K E S F

1 GLIOMLOL- - L LPIYKE TAAYGHF- - GAEHFPWE- - KT DKAOLLADAAGLK $2 V L V K E$ L D L A A - - P F Y L P T A S Y G H F - - T N O E Y P WE - - K P - K

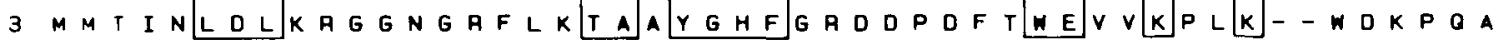

Figure 4. Comparison of the Polypeptide Sequences Encoded by the sam-1 Gene of Arabidopsis thaliana (3) and Yeast (2) (Thomas and Surdin-Kerjan, 1987) and the MetK Gene of E. coli (1) (Markham et al., 1984).

Amino acids homologous in all three sequences are boxed. The sequences have been aligned using the Intelligenetics version 5.1 computer program.

callus tissues. This probe was predominantly protected for 77 bp after $S 1$ nuclease treatment (Figure 2B). The hybridization signals of the minor protected bands vary between experiments. The amount of protected fragments using the different RNA preparations is consistent with the results obtained by RNA gel blot analysis. The leader sequence of the sam-1 gene is short since the translation start codon is located 9 nucleotides downstream from the transcription start (Figure 3). Such a short leader sequence is not unprecedented. A leader sequence of 8 nucleotides has been reported before for a gene encoding the small subunit of ribulose-1,5-bisphosphate carboxylase (rbcS3B) from tomato (Sugita et al., 1987). No obvious TATA box is present at position -30 from the transcription initiation site. From position -408 to -366 , the promoter region contains a direct repeat of 20 nucleotides separated by 3 nucleotides.

\section{DNA Gel Blot Analysis}

To determine whether this AdoMet synthetase gene (sam1) is unique in the Arabidopsis genome, a Bglll-Sall riboprobe containing $0.78 \mathrm{~kb}$ of coding sequence was hybridized to different restriction digests of genomic DNA. Using the restriction enzymes Pstl, Bglll, and EcoRI, which do not cut within the 0.78 -kb Bglll-Sall fragment, two hybridizing bands per digest were observed using moderately stringent hybridization conditions (Figure 5A). Using more stringent conditions, only one band per digest was observed (Figure 5B). The size of these at high stringency hybridizing bands is in agreement with the restriction map of the sam-1 gene. The data indicate that the sam-1 gene is a member of a gene family consisting of two different copies. A detailed analysis of the second AdoMet synthetase gene will be described elsewhere. Because the RNA 


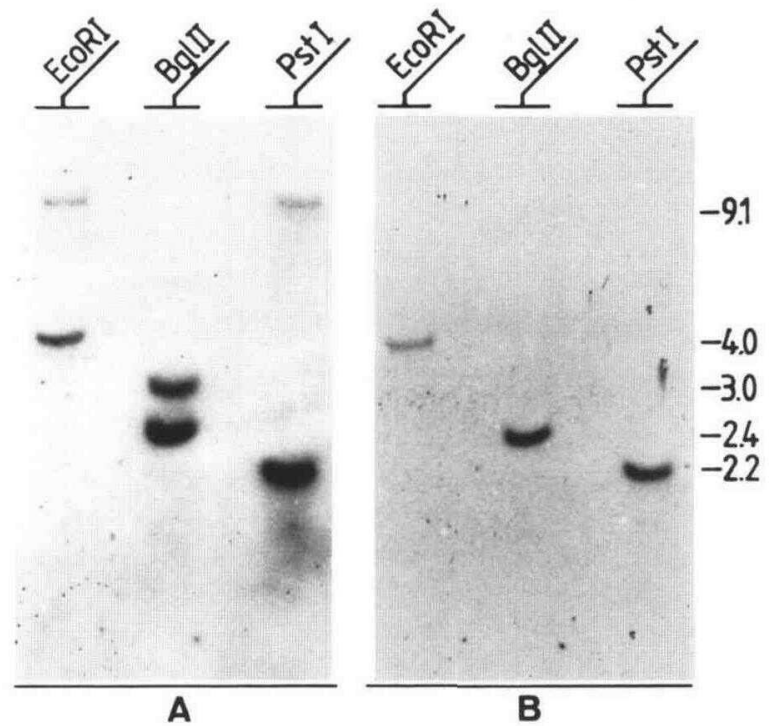

Figure 5. Arabidopsis DNA Digests Hybridized with the sam-1 Gene.

(A) A genomic DNA gel blot of $A$. thaliana DNA digested with $\mathrm{EcoRi}, \mathrm{BgIlI}$, and Pstl was hybridized with a riboprobe transcribed from the 0.78-kb Bglll-Sall fragment of the sam-1 gene as described in "Methods." The final wash was carried out in $1 \times$ SSC, $0.5 \%$ SDS at $68^{\circ} \mathrm{C}$ followed by autoradiography.

(B) The same hybridization, washed at higher stringency. Final wash was carried out in $0.1 \times \mathrm{SSC}, 0.5 \%$ SDS at $68^{\circ} \mathrm{C}$ followed by autoradiography.

gel blot hybridization (Figure 2A) has been performed using moderately stringent hybridization conditions, the expression pattern observed in Figure $2 \mathrm{~A}$ reflects the steadystate mRNA levels derived from both genes.

\section{AdoMet Synthetase Activity in Stems and Leaves of Arabidopsis}

To determine whether the levels of sam mRNA in the different organs are reflected at the protein level, AdoMet synthetase assays were performed as described in "Methods," using stem and leaf extracts. For each reaction 100 $\mu \mathrm{g}$ of crude protein extract was used. Control reactions containing all reactants, except ATP, were used to correct for background activity. The amount of incorporation of ${ }^{35} \mathrm{~S}-$ methionine into AdoMet is presented in Table 1. The results show that stem extract contains approximately 10 times more AdoMet synthetase activity than leaf extract. This corresponds closely with the 10 to 20 times higher levels of AdoMet synthetase mRNA in stems compared to leaves as seen by RNA gel blot analysis (Figure 2A).

\section{Expression of a Chimeric Gene in Transgenic Arabidopsis}

The abundance of a mRNA reflects both the efficiency of transcription and the mRNA stability. To determine the contribution of the sam-1 promoter region to the pattern of gene expression, a chimeric gene was constructed consisting of $748 \mathrm{bp}$ of promoter and $5^{\prime}$-untranslated sam1 sequences fused to the initiation codon of the $E$. coli $\beta$ glucuronidase gene (gus). As a control, a chimeric gene was constructed consisting of the gus structural gene under the control of the promoter of the ats1a gene encoding the small subunit of ribulose-1,5-bisphosphate carboxylase of Arabidopsis (Krebbers et al., 1988). The chimeric genes together with a selectable marker gene were then inserted between the T-DNA borders of the binary vector pGSC1706 yielding the plasmids pGUSSAM1 and pGUSATS-1 (Figure 6). The construction strategy of these plasmids is described in "Methods."

Transgenic $A$. thaliana (var. Columbia) plants were obtained by incubating root pieces with Agrobacterium containing these binary vectors (Valvekens et al., 1988). From the root callus, several kanamycin-resistant plants were regenerated for each construct and analyzed for $\beta$-glucuronidase (GUS) activity in the leaves, stems, and roots as described in "Methods." The plants transformed with pGUSSAM-1 show 10 to 140 times more GUS activity in stems and roots than in leaves (Table 2). The level of activity in root compared to stem is variable. By contrast, plants transformed with pGUSATS-1 show very little expression in roots and equally high expression in stems and leaves, indicating that the GUS activity reflects the properties of the promoter and not merely the stability of the messenger or the protein. Therefore, it is concluded that the 748-bp $5^{\prime}$ sequences of the sam-1 gene are at least partially responsible for the high amount of AdoMet synthetase mRNA in stems and roots.

For each chimeric construct, pGUSSAM-1 and

Table 1. In Vitro Incorporation of ${ }^{35}$ S-Methionine into AdoMet Using Stem and Leaf Protein Extracts

\begin{tabular}{lrrr}
\hline & \multicolumn{3}{l}{ Incorporation } \\
\cline { 2 - 4 } & \multicolumn{1}{c}{ +ATP } & -ATP & \multicolumn{1}{c}{ Net } \\
\hline & \multicolumn{1}{c}{ cpm } & & \\
Experiment 1 & & & \\
$\quad$ Leaf Extract & 278,516 & 31,993 & 246,523 \\
$\quad$ Stem Extract & $2,662,277$ & 51,600 & $2,610,677$ \\
Experiment 2 & & & \\
$\quad$ Leaf Extract & 272,124 & 35,334 & 236,790 \\
Stem Extract & $2,530,000$ & 31,853 & $2,498,147$ \\
\hline
\end{tabular}

Reactions proceeded for $1 \mathrm{hr}$ at $24^{\circ} \mathrm{C}$ using $100 \mu \mathrm{g}$ of crude protein extract (see "Methods"). 


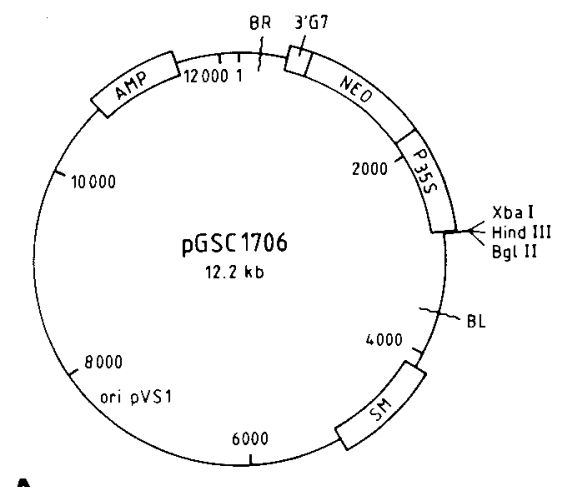

A
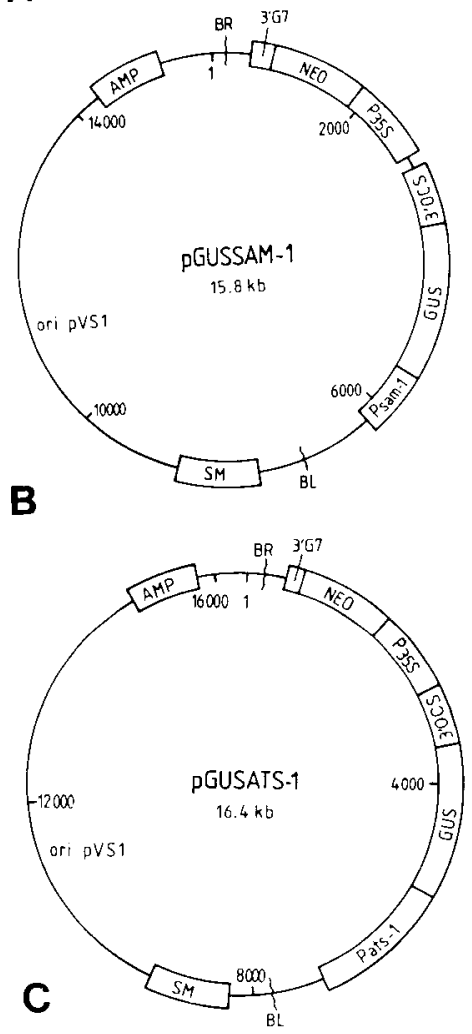

Figure 6. Maps of the Agrobacterium Plasmids Containing the Chimeric Psam-1-gus and Pats-1-gus Genes.

Construction procedure is described in "Methods." AMP, ampicillin resistance gene; $B L$, left border of the T-DNA; BR, right border of the T-DNA; GUS, $\beta$-glucuronidase gene; NEO, neomycin phosphotransferase II gene; P35S, cauliflower mosaic virus $35 \mathrm{~S}$ promoter (Odell et al., 1985); SM, streptomycin resistance gene; $3^{\prime} G 7,3^{\prime}$-untranslated end of the T-DNA gene 7 (Velten and Schell, 1985); 3' OCS, 3'-untranslated end of the T-DNA octopine synthase gene; oripVS1, origin of replication from the Pseudomonas aeruginosa plasmid pVS1 (Deblaere et al., 1987).

(A) The binary vector pGSC1706.

(B) pGUSSAM-1, containing the chimeric gene Psam-1-gus-3'ocs cloned into pGSC1706. Psam-1, 748 bp of the $5^{\prime}$-untranslated region of the sam-1 gene.

(C) pGUSATS-1, containing the chimeric gene Pats-1-gus-3'ocs cloned into pGSC1706. Pats-1, 1730 bp of the 5 '-untranslated region of the ats-1 gene.
pGUSATS-1, two representative transgenic plants were chosen for histochemical analysis (Jefferson et al., 1987). At the macroscopic level, leaves of pGUSSAM-1-transformed plants show clear GUS activity in the veins (Figure 7A). This observation shows that the GUS substrate (5bromo-4-chloro-3-indolyl- $\beta$-D-glucuronic acid; $X$-Gluc) can easily diffuse through veins. Using leaves of pGUSATS-1transformed plants, GUS activity was detected only in regions where the leaf had been cut before supplying the GUS substrate (Figure $8 \mathrm{~A}$ ).

To study the expression of the chimeric genes at the cellular level, histological preparations were made from the stained regions of leaf, stem, and root, as described in "Methods." Almost all of the visible GUS activity in pGUSSAM-1-transformed leaves was detected in the vascular tissues: xylem parenchyma cells and phloem cells (Figure 7B). Stems of these transformed plants show high GUS activity in the phloem, in the parenchyma cells of the xylem, in the sclerifying parenchyma cells between the vascular bundles, and in the pericyclic cells (Figure 7C). In both leaf and stem, a cell layer surrounding the vascular bundle also shows visibie GUS activity. When examining roots of pGUSSAM-1-transformed plants, most GUS activity is detected in the phloem and the parenchyma cells of the cortex and the secondary xylem (Figure 7, E and F).

By comparison, plants containing the pGUSATS- 1 chimeric gene show very high levels of activity in the mesophyll cells of the leaf (Figure 8B). In the stem most GUS activity is found in the cortex parenchyma (Figure 8D). Considerable GUS activity is also detected in the vascular tissues of both stem and leaf. However, the activity in the vascular tissues appears to be lower than in pGUSSAM1-transformed plants. This might explain why, at the macroscopical level, the veins of pGUSATS-1-transformed leaves show only GUS activity at the wound surface (Figure 8A). Most leaf and stem sections of pGUSATS-1-transformed plants show only a few epidermal cells with GUS activity, presumably representing guard cells. Roots have no detectable activity (Figure $8 \mathrm{E}$ ). By in situ immunofluorescence, Aoyagi et al. (1988) have shown a similar expression pattern of the small subunit of ribulose-1,5-bisphosphate carboxylase in tobacco.

\section{DISCUSSION}

In this paper, the sequence of an AdoMet synthetase gene of $A$. thaliana is presented. The polypeptide sequence of AdoMet synthetase is highly conserved even among distantly related organisms. The predicted amino acid sequence, as deduced from the sam-1 gene, is $57 \%$ homologous to the yeast enzyme and $49 \%$ to the $E$. coli enzyme. The homology with the $E$. coli and yeast enzyme extends throughout the entire polypeptide sequence. Since the amino terminus of the polypeptide is particularly highly conserved between Arabidopsis and $E$. coli, it is clear that 
Table 2. GUS Activity Using $20 \mu \mathrm{g}$ of Crude Protein Extracts from Leaf, Stem, and Root of Transgenic Plants Transformed with pGUSSAM- 1 and pGUSATS- 1

\begin{tabular}{lrrr}
\hline & Leaf & Stem & Root \\
\hline pGUSSAM-1-Transformed Plants & & & \\
C1 & 10 & 473 & 535 \\
C6 & 30 & 260 & ND $^{\mathrm{a}}$ \\
C14 & 3 & 1020 & 370 \\
C21 & 27 & 309 & 386 \\
C24 & 6 & 350 & 430 \\
C25 & 25 & 710 & 190 \\
C1000 & 20 & 400 & 1180 \\
pGUSATS-1-Transformed Plants & & & \\
B4 & 1130 & 980 & 34 \\
B61 & 535 & 523 & 5 \\
B132 & 532 & 320 & 8 \\
\hline
\end{tabular}

${ }^{a} \mathrm{ND}$, not determined.

Reactions and fluorescence measurements of the GUS product (4-methylumbelliferone) were performed as described by Jefferson et al. (1987). The values shown are the fluorescence values measured after $30 \mathrm{~min}$ reaction time. One $\mu \mathrm{M}$ of 4-methylumbelliferone has a fluorescence value of 400 .

the sam-1 gene does not code for an N-terminal transit peptide. Therefore, it seems unlikely that there would be import of the protein into chloroplasts or mitochondria.

AdoMet is needed in all living cells as methyl group donor. To this extent, the sam-1 gene can be considered as a housekeeping gene. Although most housekeeping genes are expected to be expressed constitutively, the sam-1 gene is not. RNA gel blot hybridizations of RNA from different organs show a 10- to 20-fold higher expression of the sam-1 gene in stems and roots (and callus tissue) compared with leaves, inflorescences, and seed pods. This mRNA distribution corresponds with a 10-fold difference of AdoMet synthetase activity in stems compared to leaves. This suggests that the expression of the enzyme is regulated primarily at the RNA level. To examine the expression pattern of the sam-1 gene in detail, a chimeric gene consisting of sam-1 promoter sequence fused to the coding region of the $E$. coli $\beta$-glucuronidase gene (gus) was introduced into the Arabidopsis genome. Transgenic plants containing this construct show 10 to 140 times more GUS activity in the stems and roots compared with leaves. These data indicate that the $5^{\prime}$ end of sam-1 is the major determinant for the differential expression pattern of the gene. When examining thin sections of roots, stems, and leaves of the transgenic Arabidopsis plants, high levels of GUS activity were observed in the xylem and the phloem throughout the whole plant, the sclerenchyma tissue between the vascular bundles in older parts of the stems, and in the parenchyma cells of the root cortex. Plants transformed with the gus gene under the control of the promoter of the ats 1a gene encoding the small subunit of the ribulose-1,5-bisphos- phate carboxylase contain, as expected, the highest GUS activity in the chloroplast-containing cells.

The strong cellular preference in the expression of the sam-1 gene seems to be, at least partly, correlated with the extent of lignification the tissues are undergoing: $x y-$ lem, sclerenchyma tissue, and, to a lesser extent, the phloem are known to be highly lignified (Cutter, 1978). High expression of the sam-1 gene is presumably essential in lignifying tissues. Lignin is methylated prior to polymerization: the synthesis of each monolignol needs one or two AdoMet molecules (Higuchi, 1981). Consequently, high amounts of AdoMet must be consumed in cells that produce large amounts of lignin. For some enzymes involved in lignin biosynthesis, high expression in lignifying tissues has been shown. Phenylalanine ammonialyase, which is a key enzyme in the synthesis of various phenolic compounds, including lignin, is relatively highly expressed in lignifying tissues of various plant stems compared with young undifferentiated tissues (Haddon and Northcote, 1976; Higuchi, 1981). Similarly, it has been shown that the peroxidases, which are involved specifically in lignin biosynthesis (Syr-oxidases), are active mainly in lignifying tissues such as differentiating xylem and fibers (phloem and sclerenchyma) (Catesson et al., 1986). However, this hypothesis does not explain the high expression of the sam-1 gene in the root cortex. Since AdoMet also serves for purposes other than lignin biosynthesis, such as ethylene and polyamine biosynthesis and transmethylation of many different types of molecules, other factors might as well be responsible for the high expression of the sam-1 gene in certain of the described tissues. In addition, part of the AdoMet produced in the phloem might be transported to other tissues of the plant where enzyme activity is low.

Genomic blot data indicate that there is a second sam gene in Arabidopsis, a situation that is similar to that in yeast (Thomas and Surdin-Kerjan, 1987). Isolation of the other AdoMet synthetase gene of Arabidopsis, sam-2, will allow us to study the particular expression pattern of this copy and determine whether both genes are biologically equivalent or whether they are specialized to perform separate tasks. These data can provide greater understanding of the regulatory mechanisms underlying AdoMet synthetase expression in plants.

\section{METHODS}

\section{Subclones and Riboprobes}

From the originally isolated genomic clone pATC9A1 (Simoens et al., 1988), a 4-kb EcoRl fragment and a 0.78-kb Pstl-Sall fragment containing sam-1 gene sequences were subcloned in the riboprobe system vector pGem1, yielding the plasmids pATC9A1-1 and pATC9A1-13. Riboprobes were prepared according to the Promega protocol (Promega Biotec). 

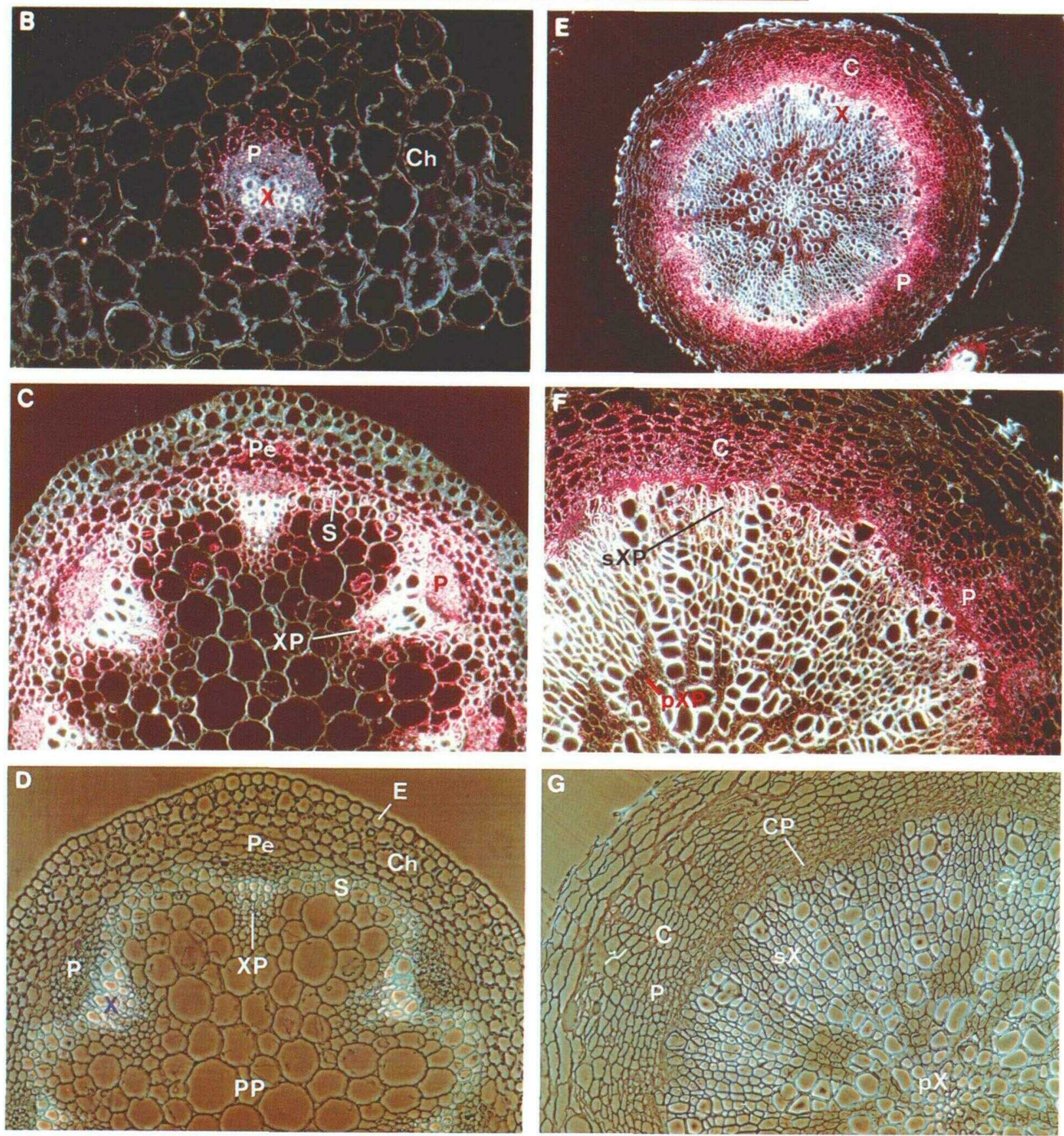

Figure 7. Histochemical Localization of GUS in pGUSSAM-1-Transformed Arabidopsis Plants.

(A) Bright-field image of leaf after staining with X-Gluc (see "Methods"). The green-blue precipitate represents regions of high GUS activity. Dark-field micrographs of transverse sections through leaf $(B)$, stem $(C)$, and roots (E and $F$ ). The red-purple stem represents GUS activity. Phase-contrast image of transverse sections of stem (D) and root (G). C, cortex parenchyma; Ch, chlorenchyma cells; CP, cambium and secondary phloem; $E$, epidermis; $P$, phloem; Pe, pericyclic cells; PP, pith parenchyma; $p X$, primary xylem; pXP, primary xylem parenchyma; S, sclerifying parenchyma; sX; secondary xylem; sXP, secondary xylem parenchyma; X, xylem; XP, xylem parenchyma. 

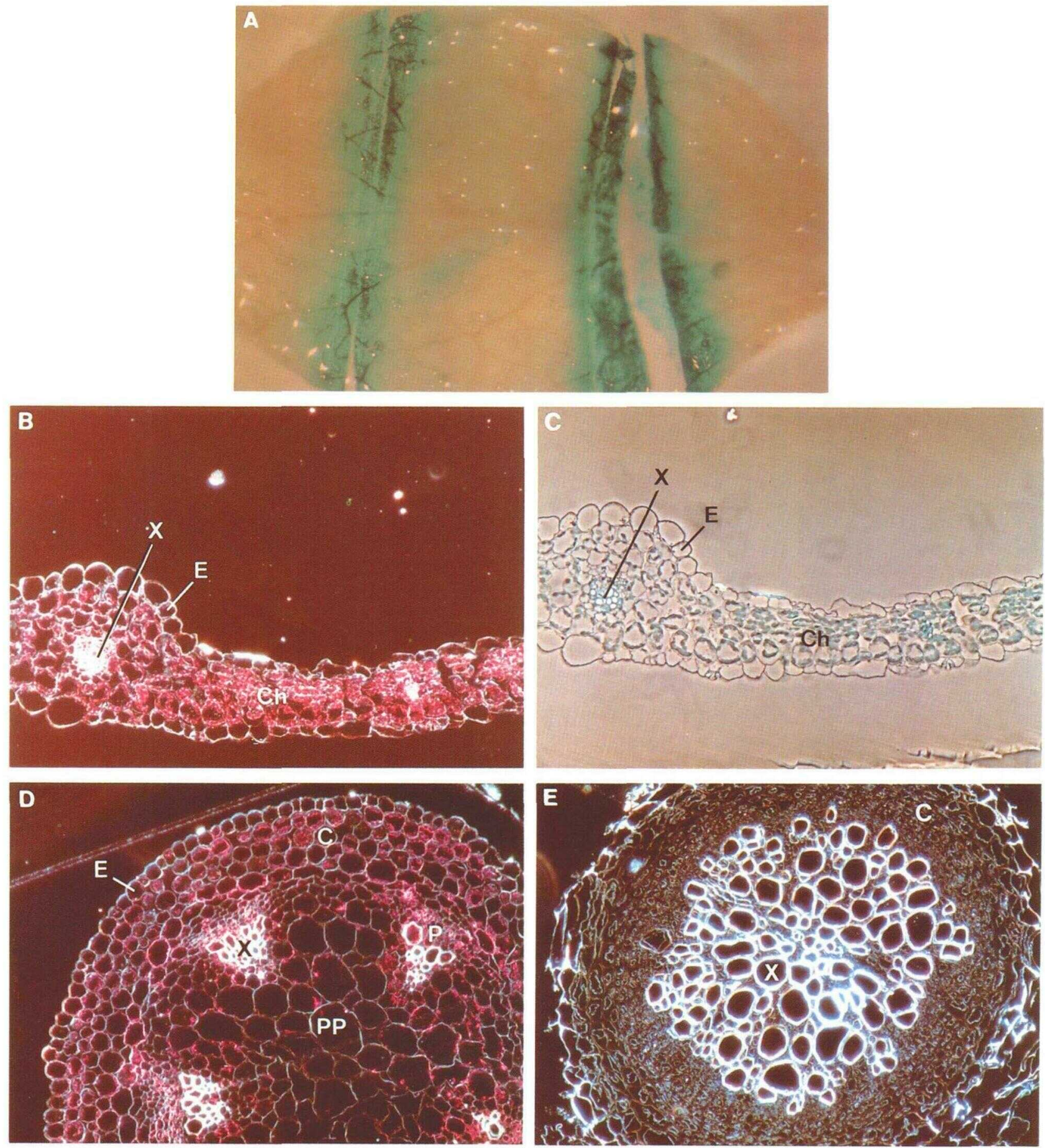

Figure 8. Histochemical Localization of GUS in pGUSATS-1-Transformed Arabidopsis Plants.

(A) Bright-field image of leaf after staining with X-Gluc (see "Methods"). Before X-Gluc incubation, the leaf was cut transversally to allow substrate infiltration. Dark-field micrographs of transverse sections through leaf (B), stem (D), and root (E). Phase-contrast image of a transverse section of a leaf (C). Abbreviations are as in Figure 7. 


\section{DNA and RNA Isolation}

Total RNAs from different organs of Arabidopsis thaliana (var. Columbia) were prepared as described by Simoens et al. (1988). Poly(A) ${ }^{+}$RNA was isolated by oligo(dT)-cellulose affinity chromatography according to Slater (1984).

DNA was isolated from Arabidopsis plants according to the procedure described by Dellaporta et al. (1983). The A. thaliana variety used to isolate DNA was obtained from the Max-PlanckInstitut für Züchtungsforschung (Köln, Federal Republic of Germany). This variety will be further referred to as var. $K 85$. When using the sam-1 gene as a probe, DNA isolated from this variety shows restriction fragment length polymorphism with the DNA isolated from the Columbia variety. The restriction pattern of the sam-1 gene isolated from the genomic library (Simoens et al., 1988 ) is identical to the restriction pattern observed with DNA from the $\mathrm{K} 85$ variety.

\section{Nucleic Acid Analysis}

For DNA gel blots, DNA was digested with appropriate restriction enzymes and run on $0.7 \%$ agarose gels, followed by transfer to nylon filters. Prehybridization and hybridization were carried out in $0.5 \mathrm{M} \mathrm{Na}_{2} \mathrm{HPO}_{4} / \mathrm{NaH}_{2} \mathrm{PO}_{4}$ (pH 7.2), $3 \% \mathrm{SDS}, 50 \mu \mathrm{g} / \mathrm{ml}$ heparin, and $0.5 \mathrm{mg}$ denatured herring sperm DNA at $68^{\circ} \mathrm{C}$ using ${ }^{32} \mathrm{P}$. labeled riboprobes. The final wash was carried out at $68^{\circ} \mathrm{C}$ in 3 $\times$ SSC, $0.5 \%$ SDS (low-stringency wash), or in $0.1 \times$ SSC, $0.5 \%$ SDS (high-stringency wash), depending on the desired stringency condition, followed by autoradiography.

For RNA gel blots, $20 \mu \mathrm{g}$ of total RNA was denatured and run on formaldehyde agarose $(1.2 \%)$ gels, followed by transfer to nylon filters. Prehybridizations and hybridizations were carried out in $5 \times \mathrm{SSC}, 50 \%$ formamide, $5 \times$ Denhardt's solution, $0.5 \%$ SDS, and $20 \mu \mathrm{g} / \mathrm{ml}$ denatured herring sperm DNA at $65^{\circ} \mathrm{C}$ using ${ }^{32} \mathrm{P}$ labeled riboprobes. The final wash was carried out in $1 \times$ SSC at $68^{\circ} \mathrm{C}$.

As size marker, an RNA ladder (Bethesda Research Laboratories) was also run on the gel. After electrophoresis, this lane was submerged in a $10 \mathrm{mg} / \mathrm{ml}$ ethidium bromide solution for 30 $\mathrm{min}$ and then destained in water overnight.

\section{S1 Mapping}

S1 mapping was performed using the method of Berk and Sharp (1977) as modified by Weaver and Weissmann (1979).

\section{Construction and Screening of a cDNA Bank}

The poly $(A)^{+}$mRNA used to construct the CDNA library was isolated from mature $A$. thaliana var. Columbia plants, grown in a 16-hr light/8-hr dark cycle at $24^{\circ} \mathrm{C}$ in a greenhouse. The RNA was isolated approximately 10 to $12 \mathrm{hr}$ after the onset of daily illumination. Double-stranded CDNAs were synthesized and then cloned in the Pstl site of pUC18 as described by De Loose et al. (1988).

The cDNA library was screened by colony hybridization essentially as described by Maniatis et al. (1982).

\section{AdoMet Synthetase Assays}

Proteins were extracted by grinding $1 \mathrm{~g}$ of stems and leaves in $0.5 \mathrm{ml}$ of $2 \times$ extraction buffer ( $100 \mathrm{~mm}$ Tris [pH 7.5], $2 \mathrm{~mm}$ EDTA, $20 \%$ glycerol, $20 \mathrm{~mm} \beta$-mercaptoethanol, $1 \mathrm{~mm}$ dithiothreitol). Debris was removed by centrifugation in an Eppendorf centrifuge at $13.000 \mathrm{rpm}$ for $5 \mathrm{~min}$. The supernatant was used as a crude enzyme preparation. The protein concentration was determined by the method of Bradford (1976) using the kit supplied by the Bio-Rad Laboratories.

The AdoMet synthetase assays were essentially as described by the method of Mudd et al. (1965). One hundred $\mu \mathrm{g}$ of proteins were incubated in $0.25 \mathrm{ml}$ of a reaction mixture containing 100 $\mathrm{mm}$ Tris (pH 8.0), $30 \mathrm{~mm} \mathrm{MgSO}, 10 \mathrm{~mm} \mathrm{KCl}, 20 \mathrm{~mm} \mathrm{ATP}$, and 5 $\mathrm{mM}{ }^{35} \mathrm{~S}$-methionine $(15 \mu \mathrm{Ci})$. Control reactions contained all reactants except ATP. After incubation for $1 \mathrm{hr}$ at $24^{\circ} \mathrm{C}$, the reaction was terminated by adding $2 \mathrm{ml}$ of ice-cold water, and the mixtures were loaded onto $0.67 \times 30 \mathrm{~cm}$ Dowex AG 50W-X2 cationexchange columns ( $\mathrm{NH}_{4}^{+}$form). Unreacted methionine and ATP were eluted by washing with $10 \mathrm{ml}$ of cold water. Adsorbed AdoMet was eluted with $5 \mathrm{ml}$ of $\mathrm{NH}_{4} \mathrm{OH}(30 \%)$. The $\mathrm{NH}_{4} \mathrm{OH}$ was evaporated, $3 \mathrm{ml}$ of universal scintillation liquid (PicoFluor, Packard) were added, and the sample was counted by scintillation spectrometry.

\section{Construction of Chimeric Genes}

A cassette was generated containing the $E$. coli $\beta$-glucuronidase coding sequence linked to the $3^{\prime}$-untranslated end of the octopine synthase gene. pOCS2 is a pUC19 plasmid (Yanisch-Perron et al., 1985) containing 700 bp of the $3^{\prime}$-untranslated end of the octopine synthase gene. This $3^{\prime}$ end was cloned as a Pstl-Hindlll fragment in the EcoRI-Hindlll sites behind the gus coding sequence in pRAJ275 (Jefferson et al., 1987), yielding the plasmid pGUS1.

As a binary T-DNA vector for the transformation experiments, pGSC1706 was used (see Figure 6A). This vector is derived from pGV943 (Deblaere et al., 1987) and contains between the T-DNA borders a chimeric gene consisting of the neomycin phosphotransferase II coding sequence under the control of the cauliflower mosaic virus $35 \mathrm{~S}$ promoter (Odell et al., 1985) and followed by the $3^{\prime}$-untranslated end of the T-DNA gene 7 (Velten and Schell, 1985). pGSC1706 also contains a polylinker fragment suitable for cloning between the T-DNA borders.

\section{Construction of a Chimeric Psam1-gus-3' ocs Gene}

An Ncol restriction site was generated at the translation initiation codon of the sam-1 gene by site-directed mutagenesis according to the protocol of $P$. Stanssens and co-workers (in preparation). To do this, the 1.19-kb EcoRI-Sall fragment of the sam-1 gene was cloned in the EcoRI-Sall sites of pMC58 (P. Stanssens and co-workers, in preparation). The 20-mer oligonucleotide $5^{\prime}$ GTCTCCATGGTGCTACAAAG- ${ }^{\prime}$, homologous to the sam-1 gene from position +16 to -4 , was used to perform the sitedirected mutagenesis. The 1.07-bp EcoRV-Sall fragment of the sam-1 gene in PATC9A1-13 was then exchanged by the mutagenized EcoRV-Sall fragment yielding the plasmid pATC9A1-13N. Subsequently, 748 bp of the sam-1 $5^{\prime}$ sequences upstream from 
the translation start were fused to the translation start codon of the $\beta$-glucuronidase gene by inserting the 751-bp Pstl-Ncol fragment of pATC9A1-13N into the polylinker between the Pstl and Ncol sites of pGUS1, yielding the plasmid pCRSGUS1.

\section{Construction of a Chimeric Pats1-gus-3' ocs Gene}

A fragment containing $1731 \mathrm{bp}$ of $5^{\prime}$ sequences upstream from the translation start of the Arabidopsis ats 1a gene (coding for the small subunit of ribulose-1,5-bisphosphate carboxylase) (Krebbers et al., 1988) was fused at the translation initiation codon with the coding sequence of the gus gene. The PLKAB2 plasmid (D. De Almeida and co-workers, in preparation) containing the ats $1 \mathrm{a}$ gene was cut with $\mathrm{Asp}^{718}$, and the $5^{\prime}$ end was treated with T4 DNA polymerase in the presence of dATP and made blunt by $\mathrm{S} 1$ nuclease. Subsequently, the plasmid was cut with EcoRI and the resulting fragment containing 1731 bp of ats 1 a 5' sequences was cloned into the Ncol site of pGUS1 yielding the plasmid pGUSS1.

Both chimeric Psam1-gus-3' ocs and Pats1-gus-3' ocs genes were cloned as a 3593-bp and 4592-bp Pvull fragment of pCRSGUS1 and pGUSS1, respectively, into the Hindlll site of the polylinker of pGSC1706 yielding the plasmids pGUSSAM-1 and pGUSATS-1. These constructs were mobilized to Agrobacterium strain C58C1Rif ${ }^{R}$ containing the vir plasmid pGV2260 (Deblaere et al., 1985) by triparental mating (Van Haute et al., 1983).

\section{Transformation of Arabidopsis}

A. thaliana var. Columbia was transformed using root explants according to the method described by Valvekens et al. (1988).

\section{$\beta$-Glucuronidase Assays}

\section{Fluorometrical GUS Assay}

GUS assays with protein extracts of leaves, stems, and roots were carried out using the fluorometric assay procedure described by Jefferson et al. (1987). Protein concentrations of the various plant extracts were determined by the method of Bradford (1976) using the kit supplied by Bio-Rad Laboratories.

\section{Histochemical GUS Assay}

The histochemical localization of GUS in transformed plants was performed essentially as described by Jefferson et al. (1987) with some modifications.

Fresh plant material was cut by hand in small blocks of about $1 \mathrm{~mm}^{3}$ and immersed immediately in a histochemical reaction mixture containing $0.5 \mathrm{mg} / \mathrm{ml}$ 5-bromo-4-chloro-3-indolyl- $\beta$-D-glucuronic acid ( $X$-Gluc, Research Organics, Inc., Cleveland, $O H$ ) in $100 \mathrm{~mm}$ sodium phosphate buffer $(\mathrm{pH}$ 7.3). $X$-Gluc was dissolved in ethylene glycol monomethyl ether at $50 \mathrm{mg} / \mathrm{ml}$ and then diluted into the reaction mixture. Cutting of larger plant organs into smaller blocks is crucial to allow proper substrate infiltration. Thin roots and small seedlings of Arabidopsis can be treated as a whole. The histochemical reaction was performed in the dark at $37^{\circ} \mathrm{C}$ until a blue indigo color appeared. To stop the reaction, tissues were rinsed several times in $100 \mathrm{~mm}$ phosphate buffer followed by fixation in a phosphate-buffered $1 \%$ glutaraldehyde solution for $3 \mathrm{hr}$ at $4^{\circ} \mathrm{C}$ and a final rinse in phosphate buffer.

To allow a better visualization of the indigo stain, tissue blocks were cleared in $70 \%$ ethanol overnight to remove chlorophyll. Photographs from whole mounts of tissue blocks were taken at low power magnification using bright-field microscopy.

Thin sections of positively stained plant material were prepared according to the following protocol. After $X$-Gluc staining and rinsing in phosphate buffer, tissue blocks were dehydrated by immersion into a series of aqueous ethanol solutions from $30 \%$ to $95 \%$ and then in $100 \%$ ethanol for $2 \mathrm{hr}$ at room temperature. A gradual infusion with the acrylic resin LR white (London Resin, London, United Kingdom) was carried out using ethanol/LR white mixtures of $2 / 1,1 / 1$, and $1 / 2$ for $2 \mathrm{hr}$ each at room temperature. A final infusion with $100 \%$ LR white was performed overnight at $4^{\circ} \mathrm{C}$. Polymerization was done overnight in gelatin capsules at $60^{\circ} \mathrm{C}$. After hardening, the specimens were cut into thin sections using glass knives fitted to a Reichert microtome Ultracut $E$. Care was taken during sectioning to ensure that only well-stained regions close to the surface of the tissue blocks were processed. Two- to 4- $\mu \mathrm{m}$ sections were picked up dry and transferred on drops of distilled water on a glass slide. Sections were flattened by moving the glass slides carefully in a flame until completely dry. Finally, specimens were mounted without counterstaining with DePeX mounting medium and a coverslip and were allowed to harden overnight. Photographs were taken by dark-field microscopy.

\section{Miscellaneous Techniques}

All recombinant DNA techniques not described above were performed according to Maniatis et al. (1982). The DNA sequence was determined on both strands by the procedure of Maxam and Gilbert (1980). Nucleotide comparison analysis was done using the Intelligenetics software package for molecular biologists.

\section{ACKNOWLEDGMENTS}

We thank Drs. A. Caplan, E. Krebbers, and P. Dhaese for critical reading of the manuscript, J. Coppieters and $\mathrm{I}$. Zaenen for computer work, Dr. P. Goetghebeur for assistance in the interpretation of the thin sections, B. Cottyn and M. Habets for technical assistance, M. Davis for musical support, and M. De Cock, K. Spruyt, S. Van Gijsegem, and V. Vermaercke for help in preparing the manuscript. This work was supported by grants from the A.S.L.K.-Kankerfonds, the Fonds voor Geneeskundig Wetenschappelijk Onderzoek (F.G.W.O. 3.0001.82), and the Services of the Prime Minister (O.O.A. 12.0561 .84 and U.I.A.P. 120C0187). J.P. and W.B. are indebted to the Instituut tot Aanmoediging van het Wetenschappelijk Onderzoek in Nijverheid en Landbouw for a fellowship and T.A. to L'Air Liquide S.A. for financial support. D.I. is a Senior Research Assistant of the National Fund for Scientific Research (Belgium).

Received October 26, 1988. 


\section{REFERENCES}

Aarnes, H. 1977). Partial purification and characterization of methionine adenosyltransferase from pea seedlings. Plant Sci. Lett. 10, 381-390.

Abe, T., Yamano, H., Teraoka, H., and Tsukada, K. (1980). Changes in the activities of $S$-adenosylmethionine synthetase isozymes from rat liver on ethionine administration. FEBS Lett. 121, 29-32.

Aoyagi, K., Kuhlemeier, C., and Chua, N.-H. (1988). The pea rbcs-3A enhancer-like element directs cell-specific expression in transgenic tobacco. Mol. Gen. Genet. 213, 179-185.

Berk, A.J., and Sharp, P.A. (1977). Sizing and mapping of early adenovirus mRNAs by gel electrophoresis of $\mathrm{S} 1$ endonucleasedigested hybrids. Cell 12, 721-732.

Bradford, M.M. (1976). A rapid and sensitive method for the quantitation of microgram quantities of protein utilizing the principle of protein-dye binding. Anal. Biochem. 72, 248-254.

Catesson, A.-M., Imberty, A., Goldberg, R., and Czaninski, Y. (1986). Nature, localization and specificity of peroxidases involved in lignification processes. In Molecular and Physiolqgical Aspects of Plant Peroxidases. H. Greppin, C. Penel, and T. Gaspar, ed (Geneva: University of Geneva), pp. 189-198.

Cherest, H., Surdin-Kerjan, Y., Exinger, F., and Lacroute, F. (1978). S-adenosyl methionine requiring mutants in Saccharomyces cerevisiae: Evidences for the existence of two methionine adenosyl transferases. Mol. Gen. Genet. 163, 153-167.

Cutter, E.D. (1978). Plant Anatomy, Part I: Cells and Tissues (London: Edward Arnold Publishers).

De Loose, M., Alliotte, T., Gheysen, G., Genetello, C., Gielen, J., Soetaert, P., Van Montagu, M., and Inzé, D. (1988). Primary structure of a hormonally regulated $\beta$-glucanase of Nicotiana plumbaginifolia. Gene (Amst.) 70, 13-23

Deblaere, R., Bytebier, B., De Greve, H., Deboeck, F., Schell, J., Van Montagu, M., and Leemans, J. (1985). Efficient octopine Ti plasmid-derived vectors for Agrobacterium-mediated gene transfer to plants. Nucleic Acids Res. 13, 4777-4788.

Deblaere, R., Reynaerts, A., Höfte, H., Hernalsteens, J.-P., Leemans, J., and Van Montagu, M. (1987). Vectors for cloning in plant cells. Methods Enzymol. 153, 277-292.

Dellaporta, S.L., Wood, J., Hicks, J.B. (1983). A plant DNA minipreparation: Version II. Plant Mol. Biol. Rep. 1, 19-21.

Giovanelli, J., Mudd, S.H., and Datko, A.H. (1980). Sulfur amino acids in plants. In Amino Acids and Derivatives. The Biochemistry of Plants: A comprehensive treatise, Vol. 5, B.J. Miflin, ed, (New York: Academic Press), pp. 453-505.

Haddon, L., and Northcote, D.H. (1976). Correlation of the induction of various enzymes concerned with phenylpropanoid and lignin synthesis during differentiation of bean callus (Phaseolus vulgaris L.). Planta (Berl.) 128, 255-262.

Higuchi, T. (1981). Biosynthesis of lignin. In Plant Carbohydrates II. Encyclopedia of Plant Physiology, New Series Vol. 13B, W. Tanner and F.A. Loewus, eds (Berlin: Springer-Verlag), pp. 194224.

Jefferson, R.A., Kavanagh, T.A., and Bevan, M.W. (1987). GUS fusions: $\beta$-Glucuronidase as a sensitive and versatile gene fusion marker in higher plants. EMBO J. 6, 3901-3907.
Krebbers, E., Seurinck, J., Herdies, L., Cashmore, A.R., and Timko, M.P. (1988). Four genes in two diverged subfamilies encode the ribulose-1,5-bisphosphate carboxylase small subunit polypeptides of Arabidopsis thaliana. Plant Mol. Biol., in press.

Maniatis, T., Fritsch, E.F., and Sambrook, J. (1982). Molecular Cloning, A Laboratory Manual. (Cold Spring Harbor, NY: Cold Spring Harbor Laboratory).

Markham, G.D., Hafner, E.W., Tabor, C.W., and Tabor, H. (1980) S-Adenosylmethionine synthetase from Escherichia coli. J. Biol. Chem. 255, 9082-9092.

Markham, G.D., DeParasis, J., and Gatmaitan, J. (1984). The sequence of metK, the structural gene for S-adenosylmethionine synthetase in Escherichia coli. J. Biol. Chem. 259, 1450514507.

Maxam, A.M., and Gilbert, W. (1980). Sequencing end-labeled DNA with base-specific chemical cleavages. Methods Enzymol. 65, 499-559.

Mudd, S.H. (1960). S-Adenosylmethionine formation by barley extracts. Biochim. Biophys. Acta 38, 354-355.

Mudd, S.H., Finkelstein, J.D., Irreverre, F., and Laster, L. (1965). Transsulfuration in mammals. Microassays and tissue distributions of three enzymes of the pathway. J. Biol. Chem. 240, 4382-4392.

Odell, J.T., Nagy, F., and Chua, N.-H. (1985). Identification of DNA sequences required for the activity of the cauliflower mosaic virus $35 \mathrm{~S}$ promoter. Nature (Lond.) 313, 810-812.

Simoens, C., Peleman, J., Valvekens, D., Van Montagu, M., and Inzé, D. (1988). Isolation of genes expressed in specific tissues of Arabidopsis thaliana by differential screening of a genomic library. Gene (Amst.) 67, 1-11.

Slater, R.J. (1984). The purification of poly(A)-containing RNA by affinity chromatography. In Methods in Molecular Biology, Vol. 2, J.M. Walker, ed (Clifton, NJ: Humana Press), pp. 117-120.

Sugita, M., Manzara, T., Pichersky, E., Cashmore, A., and Gruissem, W. (1987). Genomic organization, sequence analysis and expression of all five genes encoding the small subunit of ribulose-1,5-bisphosphate carboxylase/oxygenase from tomato. Mol. Gen. Genet. 209, 247-256.

Suma, Y., Shimizu, K., and Tsukada, K. (1986). Isozymes of $S$ adenosylmethionine synthetase from rat liver: isolation and characterization. J. Biochem. (Tokyo) 100, 67-75.

Tabor, C.W., and Tabor, H. (1984). Methionine adenosyltransferase (S-adenosylmethionine synthetase) and S-adenosylmethionine decarboxylase. Adv. Enzymol. 56, 251-282.

Thomas, D., and Surdin-Kerjan, Y. (1987). SAM1, the structural gene for one of the $S$-adenosylmethionine synthetases in Saccharomyces cerevisiae. J. Biol. Chem. 262, 16704-16709.

Valvekens, D., Van Montagu, M., and Van Lijsebettens, M. (1988). Agrobacterium tumefaciens-mediated transformation of Arabidopsis root explants using kanamycin selection. Proc. Natl. Acad. Sci. USA 85, 5536-5540.

Van Haute, E., Joos, H., Maes, M., Warren, G., Van Montagu, M., and Schell, J. (1983). Intergeneric transfer and exchange recombination of restriction fragments cloned in pBR322: a novel strategy for the reversed genetics of $\mathrm{Ti}$ plasmids of Agrobacterium tumefaciens. EMBO J. 2, 411-418. 
Velten, J., and Schell, J. (1985). Selection-expression plasmid vectors for use in genetic transformation of higher plants. Nucleic Acids Res. 13, 6981-6998.

Weaver, R., and Weissmann, C. (1979). Mapping of RNA by a modification of the Berk-Sharp procedure: The $5^{\prime}$ termini of the $15 S \beta$-globin mRNA precursor and mature 10S $\beta$-globin mRNA have identical map coordinates. Nucleic Acids Res. 7, 11751193.
Yang, S.F., and Hoffman, N.E. (1984). Ethylene biosynthesis and its regulation in higher plants. Annu. Rev. Plant Physiol. 35, 155-189.

Yanisch-Perron, C., Vieira, J., and Messing, J. (1985). Improved M13 phage cloning vectors and host strains: nucleotide sequences of the M13mp18 and pUC19 vectors. Gene (Amst.) 33, 103-119. 